\title{
RANCANG BANGUN ALAT CETAK KOMPOSIT SAMPAH PLASTIK DENGAN SABUT KELAPA
}

\author{
Priyono $^{1}$, Artian Sirun ${ }^{2}$, Ivonne Fredika Yunita Polii ${ }^{3}$ \\ 1,2,3(Jurusan Teknik Mesin/DIII Teknik Mesin, Politeknik Negeri Manado) \\ Priyonosst3@gmail.com \\ sirunartian@yahoo.co.id \\ ${ }^{3}$ Ivonne080675@gmail.com
}

\begin{abstract}
Abstrak - Alat cetak komposit sampah plastik dengan serat sabut kelapa dirancang dengan tujuan dapat mengubah sampah plastik jenis HDPE kususnya penutup botol minuman dengan serat sabut kelapa menjadi suatu produk berbentuk papan komposit (panel) yang lebih bermanfaat. Dimensi cetakan 410 x $540 \mathrm{~mm}$, tinggi alat $850 \mathrm{~mm}$ lebar $600 \mathrm{~mm}$ Panjang $600 \mathrm{~mm}$, temperature elemen pemanas yang terpasang berkisar 200 - 250 derajat sebanyak 12 buah, $220 \mathrm{~V} 1000$ watt, sedangkan penekannya menggunakan dongkrak hidrolik 10 ton. Temperature pemanasan untuk pengepresan papan komposit diatur berkisar $130^{\circ}-180^{\circ} \mathrm{C}$. Dari hasil uji coba alat cetak pertama dengan material plat besi, produk yang dihasilkan lengket pada permukaan plat, pengujian kedua dilapisi dengan alumunium foil, produk yang di hasilkan kurang sempurna karena permukaannya tidak rata, sedangkan pengujian ke tiga cetakan di lapisi dengan plat stainless steel, produk yang dihasilkan lebih baik dari hasil cetakan yang dilakukan sebelumnya. Penelitian ini perlu ditingkatkan guna membantu pemerintah dalam penanganan sampah plastic, selain itu hasil produk dengan alat ini akan membantu meningkatkan ketrampilan masyarakat serta meningkatkan perekonomian dari hasil produk alat ini.
\end{abstract}

Kata kunci: Alat cetak; Komposit; serat sabut kelapa; HDPE,

Abstract - The plastic waste composite molding tool with coconut fiber is designed with the aim of converting HDPE type plastic waste, especially drink bottle covers with coconut fiber into a product in the form of a composite board (panel) that is more useful. The dimensions of the mold are $410 \times 540 \mathrm{~mm}$, the tool height is $850 \mathrm{~mm}$, the width is $600 \mathrm{~mm}$, the length is $600 \mathrm{~mm}$, the temperature of the installed heating elements is around 200-250 degrees for 12 pieces, $220 \mathrm{~V} 1000$ watts, while the press uses a 10 ton hydraulic jack. The heating temperature for pressing the composite board is set in the range of $130^{\circ}-180^{\circ} \mathrm{C}$. From the results of the first printing press with iron plate material, the resulting product is sticky on the plate surface, the second test is coated with aluminum foil, the resulting product is less than perfect because the surface is uneven., while the three molds were coated with stainless steel plates, the resulting product was better than the results of the previous molds. This research needs to be improved in order to assist the government in handling plastic waste, in addition to the results of products with this tool will help improve people's skills and improve the economy of the products of this tool.

Keywords: Printing equipment; Composite; coco fiber; HDPE

\section{PENDAHULUAN}

Heri Saptono (2021) Dari data jumlah penduduk Kota manado yang hampir 500.000 jiwa ternyata sampah yang dihasilkan bisa mencapai lebih 250 ton untuk setiap harinya yang terbuang ke Tempat Pembuangan Akhir (TPA) tanpa ada solusi di tingkat bawah, agar supaya sampah yang terbuang di TPA tinggal residunya. Mengharapkan juga ada perlakukan di tingkat bawah dalam arti baik di tingkat lingkungan, kelurahan, kecamatan dan seterusnya. Agar sampah plastic tidak menumpuk di TPA, maka sampah tersebut harus dilakukan daur ulang menjadi suatu produk yang bermanfaat dan dapat meningkatkan ekonomi masyarakat.

Rizal Hanifi (2019) Membuat mesin cetak hidrolik 20 ton dengan suhu untuk pemanasan berkisar antara $120^{\circ} \mathrm{C}-200{ }^{\circ} \mathrm{C}$, ukuran mesin lebar $60 \mathrm{~cm}$, Tinggi $130 \mathrm{~cm}$ dan ukuran Panjang cetakan papan komposit $54 \mathrm{~cm}$ dan lebarnya $20 \mathrm{~cm}$, dengan menggunakan elemen pemanas 4 buah., hasil yang baik pada temperatur $150^{\circ} \mathrm{C}$, dan $170{ }^{\circ} \mathrm{C}$.

Irvan Okatama (2016), peleburan limbah plastik jenis (PET) menjadi biji plastik melalui pengujian alat pelebur plastik, menggunakan alat pemanas Heater Band dan Heater Nozzle suhu pemanasan berkisar $100^{\circ} \mathrm{C}-300^{\circ} \mathrm{C}$. Kapasitas produksi potongan plastik bisa mencapai 1 kilogram, bahan plastik (PET) melunak pada suhu $180^{\circ} \mathrm{C}$ dan mencair secara sempurna pada suhu $200^{\circ} \mathrm{C}$.

Ardi Juniarto (2018), Pemanfaatan Limbah Plastik Polipropilen Sebagai Matrial Komposit Sampah Plastik Biodegradable Dengan Penambahan Serbuk Ampas Aren memiliki titik lebur $\sim 160^{\circ} \mathrm{C}\left(320^{\circ} \mathrm{F}\right)$.

Mulinari, D.R., (2011), dalam pengamatannya mengatakan bahwa serat kelapa yang diberi perlakuan memberikan stabilitas termal yang lebih tinggi dibandingkan dengan serat yang tidak diberi perlakuan. Hal ini terjadi pada kisaran suhu $220-380^{\circ} \mathrm{C}$, residu ini disebabkan oleh dekomposisi sampel.

Penelitian ini bertujuan untuk membantu pemerintah dalam penanggulangan sampah plastik, mendaur ulang menjadi bentuk papan komposit. Sehingga alat cetak ini dapat bermanfaat untuk masyarakat luas dalam ikut serta menanggulangi sampah plastik diubah menjadi barang yang bernilai jual. 


\section{METODE}

Pada rancang bangun alat cetak sampah plastic HDPE (kusunya penutup botol minuman) dengan sabut kelapa, proses penekanannya dengan dongkrak dan membukanya dengan pegas tekan.Plat cetakan atas dan bawah menggunakan plat steel dengan ketebalan $5 \mathrm{~mm}$. berikut adalah gambar rancangan alat cetak :

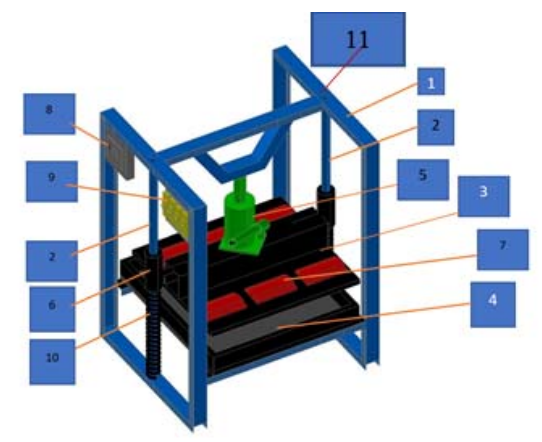

Gambar 1 Rancangan alat cetak

Keterangan gambar

1. Rangka utama

2. Poros pengarah

3. Cetakan atas

7. Elemen pemanas

4. Cetakan bawah

8. Termostart

5. Dongkrak

9. Panel MCB

10. Pegas tekan

Pada permukaan plat cetakan penekan atas dan cetakan bawah dipasang elemen pemanas masing masing sebanyak 6 buah dengan temperature $250^{\circ} \mathrm{C}$.

Bahan dan alat yang di gunakan: untuk rangka utama besi UNP80 x $200 \mathrm{~mm}$ tebal $7.5 \mathrm{~mm}$, besi plat tebal $5 \mathrm{~mm}$, dongkrak hidrolik 10 ton, pegas tekan, termostart,alumunium foil, plat staenless, mcb, panel listrik, elemen pemanas $250^{\circ} \mathrm{C}$ sebanyak 12 buah,sampah plastic HDPE, serat sabut kelapa, mesin las ,mesin potong, dan alat pendukung lainnya.

Proses pencetakan komposit sampah plastic HDPE dan serat sabut kelapa temperature pemanasan diatur pada suhu $140^{\circ} \mathrm{C}$, pada temperature tersebut plastic HDPE sudah mencair Langkah selanjutnya elemen pemanas di matikan yang kemudian dilakukan pendinginan. Untuk mempercepat proses pendinginan ditiupkan udara dengan menggunakan blower pada cetakan atas dan bawah. Setelah mencapai pada suhu ruangan, cetakan atas dibuka dengan cara membuka katup pengunci pada dongkrak hidrolik yang dibantu oleh pegas tekan untuk menggerakan cetakan atas membuka.

Sampah plastik yang akan digunakan untuk proses uji coba alat cetak, terlebih dahulu dihancurkan untuk mempercepat proses pencairannya.

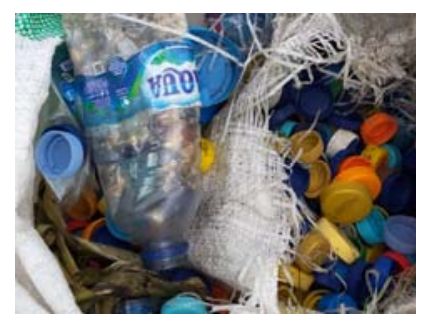

Gambar 2 Raw Material Sampah Plastik.

Gambar 2 menunjukan Raw material berbagai macam penutup botol yang di gunakan untuk uji coba alat
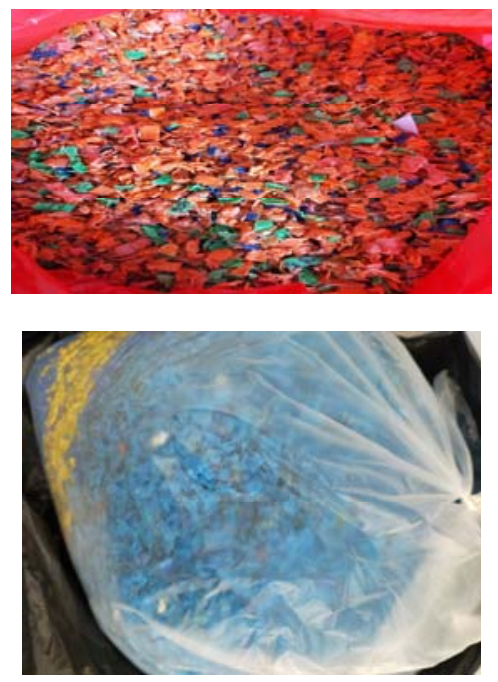

Gambar 3 Raw Material Sampah Plastik siap pakai.

Gambar 3 menunjukan bahan baku penutup botol yang akan digunakan untuk uji coba alat sudah dihancurkan terlebih dahulu menjadi butiran kecil agar dalam proses peleburan akan lebih cepat.

\section{HASIL DAN DISKUSI}

Dari hasil rancang bangun alat cetak komposit sampah plastik HDPE dan serat sabut kelapa, seperti pada gambar dibawah: 
Desain Cetakan Bawah
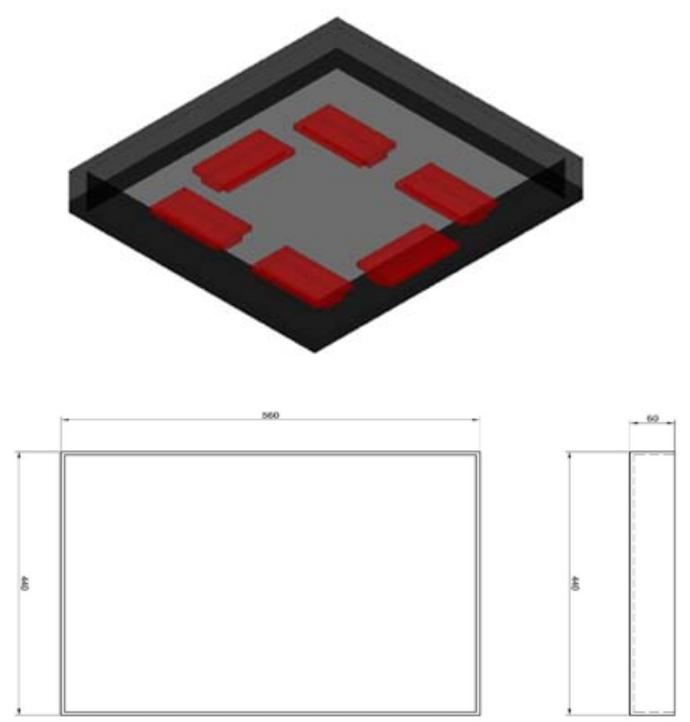

Gambar 4 Cetakan bawah

Gambar 4 menunjukan cetakan bawah dengan dimensi bagian dalam panjang $550 \mathrm{~mm}$ dan lebar $430 \mathrm{~mm}$, yang berfungsi sebagai wadah untuk menampung material sampah plastik dan sabut kelapa yang akan di cetak menjadi komposit. Pada bagian bawah plat cetakan terpasang elemen pemanas sebanyak 6 buah dengan temperatur berkisar 200-250 derajat celcius.

\section{Desain Rangka Utama}

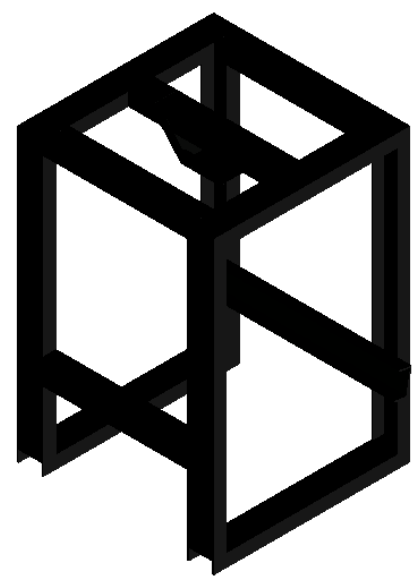

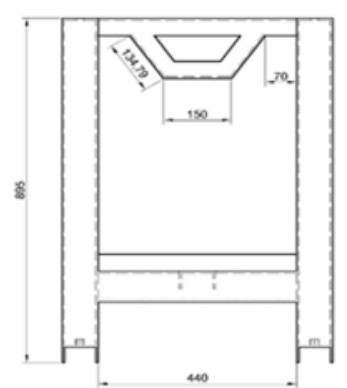

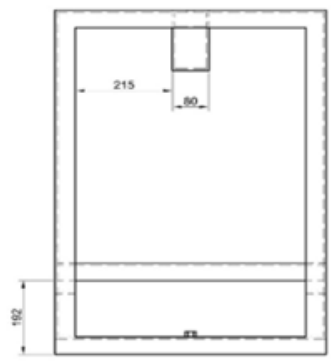

Gambar 5 Rangka utama

Gambar 5 Rangka utama sebagai dudukan cetakan atas dan cetakan bawah serta pada bagian kanan kirinya terpasang poros pengarah yang berfungsi untuk mengarahkan cetakan atas bergerak keatas dan kebawah.

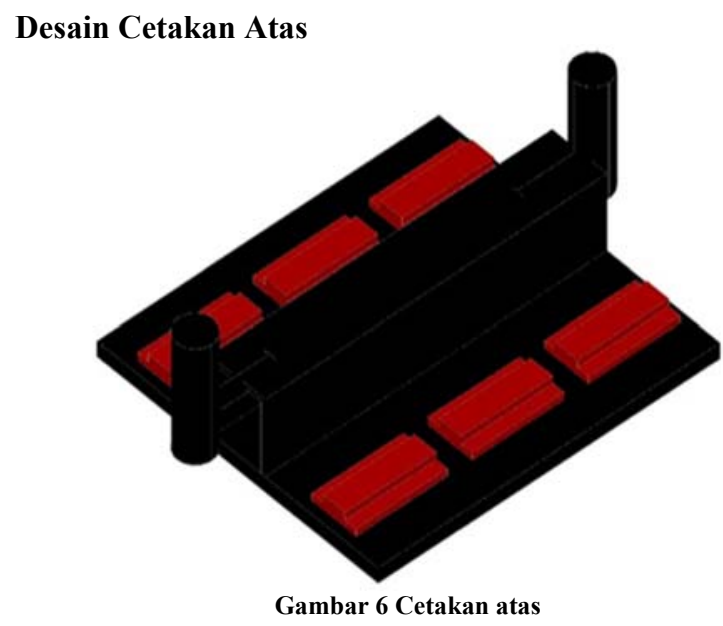

Gambar 6 menunjukan cetakan atas pada bagian permukaan plat ditempatkan elemen pemanas sebanyak 6 buah, dibagian tengah kanan kirinya terpasang pengarah cetakan yang berfungsi agar cetakan atas dapat bergerak lurus masuk ke cetakan bawah.

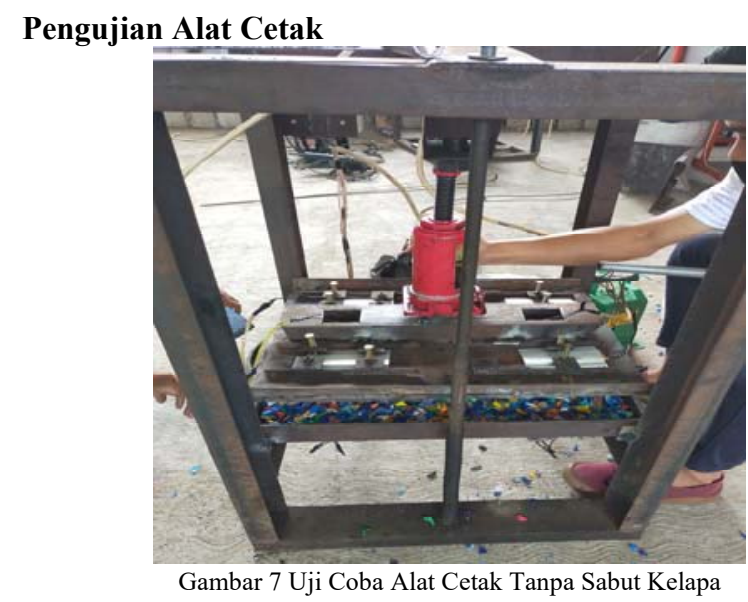


Gambar 7 menunjukan pengujian alat cetak dimana material yang digunakan sampah plastik HDPE sebanyak $2 \mathrm{Kg}$ yang belum ditambahkan dengan sabut kelapa, pengepresan dengan menggunakan dongkrak hidrolik yang bertujuan mencetak sampah plastik yang dilanjutkan dengan peleburan menjadi bentuk papan.

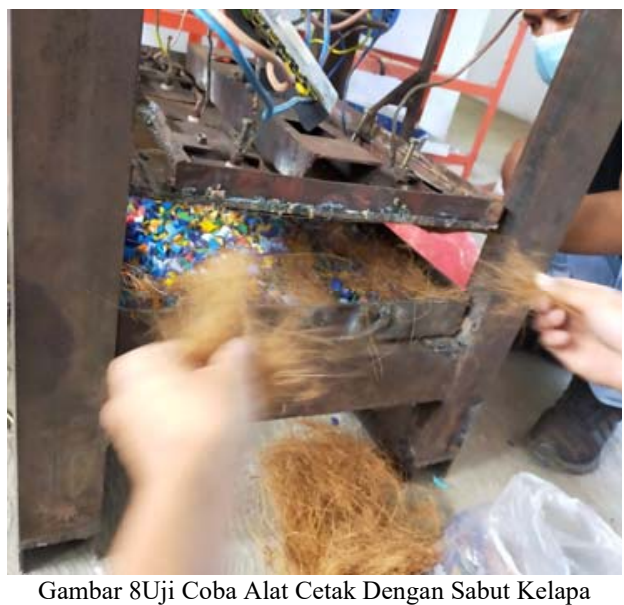

Gambar 8 menunjukan pengujian alat cetak dengan material sampah plastik HDPE sebanyak $2 \mathrm{Kg}$ yang ditambahkan sabut kelapa sebanyak 50 gram.

Alat cetak terdiri dari beberapa bagian, antara lain :

1. Rangka utama sebagai dudukan cetakan atas dan bawah.

2. Dongkrak hidrolik berfungsi menekan cetakan atas kearah cetakan bawah

3. Poros pengarah yang berfungsi unuk mengarahkan cetakan atas menuju cetakan bawah.

4. Elemen pemanas temperature $250^{\circ} \mathrm{C}$ ditempatkan pada permukaan cetakan atas, yang berfungsi untuk mencairkan sampah plastic HDPE yang sudah dihancurkan menjadi potongan kecil-kecil.

5. Cetakan bawah ini juga dipasang elemen pemanas temperature $250^{\circ} \mathrm{C}$, sebagai wadah membentuk komposit sampah plastic hdpe yang dicampur dengan serta sabut kelapa.

6. Pegas tekan yang berfungsi untuk menaikan cetakan atas setelah selesai mencetak komposit.

7. Elemen pemanas yang berfungsi untuk mencairkan sampah plasstik HDPE sampai dengan temperature antara $120^{\circ}-140^{\circ} \mathrm{C}$

Hasil Uji Cetak Komposit

Uji Cetak ke 1 Tanpa sabut kelapa

Pengujian pertama dengan menggunakan cetakan plat steel.

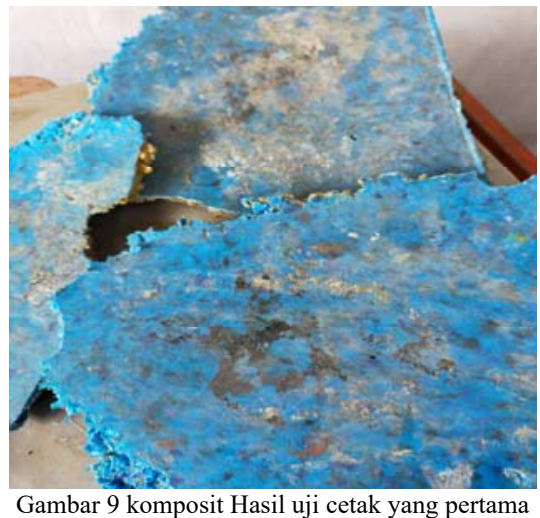

Temperatur pemanasan uji cetak pertama pada suhu $225^{\circ} \mathrm{C}$, hasil dari uji coba alat belum berhasil dikarenakan hasil dari komposit lengket pada permukaan cetakan plat steel hal ini disebabkan proses pemanasan terlalu tinggi dan juga pendinginannya terlalu lama mencapai 12 jam, cetakan papan komposit yang dihasilkan tidak sempurna dan getas.

\section{Uji alat cetak ke 2 tanpa sabut kelapa}

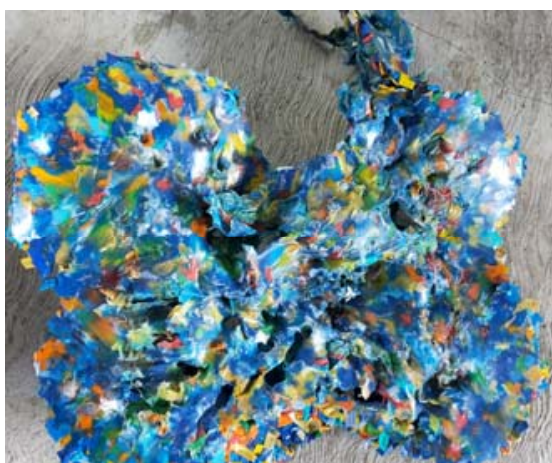

Gambar 10 Komposit Hasil Uji Cetak Kedua Tanpa Sabut Kelapa.

Dari uji cetak kedua dengan plat steel dan temperature pemasanan berkisar $140-150^{\circ} \mathrm{C}$ masih gagal, hasil cetakan papan komposit belum mendapatkan hasil sempurna hal ini disebabkan material lengket pada permukaan plat steel yang disebabkan material belum dingin, masih pada suhu sekitar $80^{\circ} \mathrm{C}$ cetakan dibuka papan komposit yang dicetak belum mengeras. 
Uji Alat Cetak ke 3

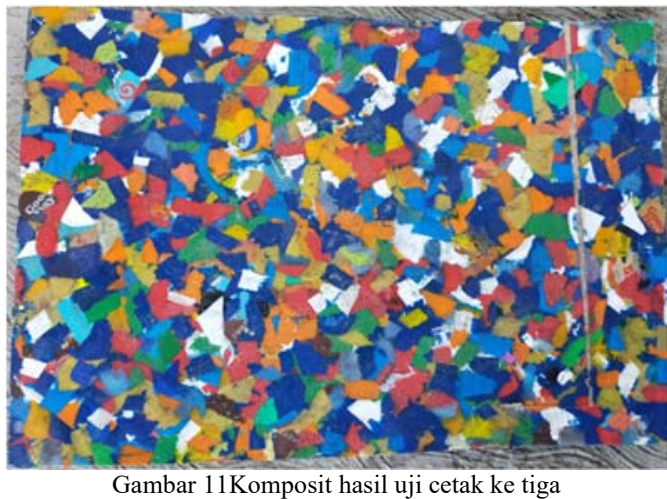

Pada uji cetak yang ke 3 permukaan cetakan atas dan bawah di lapisi dengan alumunium foil mendapatkan hasil produk komposit yang baik, pada temperatur $120-150{ }^{\circ} \mathrm{C}$ dengan fisik warna yang sama dengan sampah plastik yang di olah tetapi permukaan dari komposit tidak rata atau licin, material sampah plastik yang dilelehkan dengan elemen pemanas tidak lengket pada plat tetapi lengket pada alumunium foil.

\section{Uji Alat Cetak ke 4}

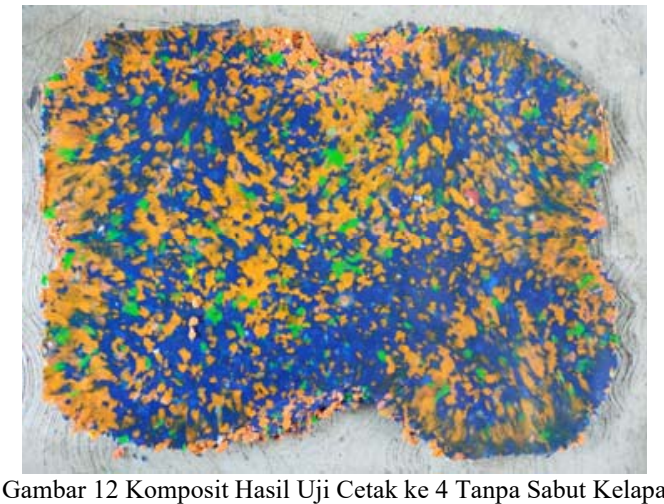

Pengujian ke 4 permukaan plat cetakan dilapisi dengan staenless steel tebal $1,2 \mathrm{~mm}$, belum mendapatkan hasil yang baik, tetapi hasil cetakan tidak lengket pada permukaan plat staenless, hal ini dikarenakan elemen pemanas yang digunakan terjadi kerusakan yang menyebabkan panas tidak merata pada seluruh permukaan plat.

\section{Uji Alat Cetak ke 5}

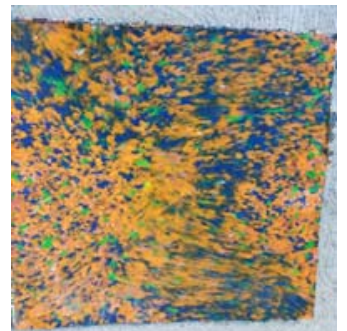

Gambar 13 Komposit Hasil Cetak ke 5
Pada uji cetak yang ke 5 permukaan cetakan atas dan bawah dilapisi dengan plat staenless steel mendapatkan hasil produk komposit yang baik, pada temperatur $155^{\circ} \mathrm{C}$ dengan fisik warna yang sama dengan sampah plastik raw material dan juga permukaan dari komposit licin, material sampah plastik dilelehkan dengan elemen pemanas tidak lengket pada permukaan staenless steel.

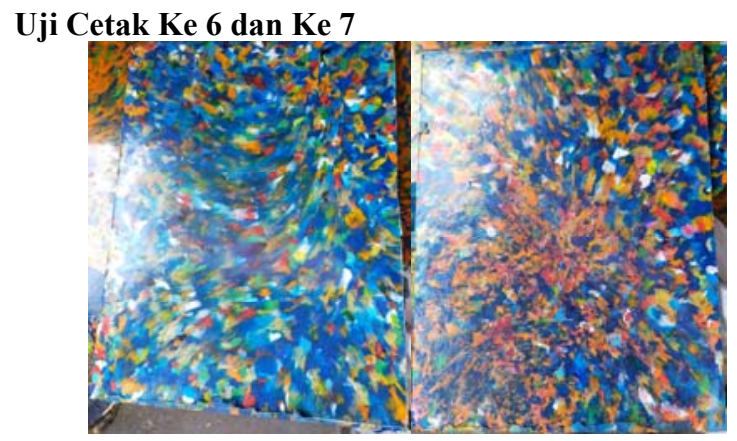

Pada uji cetak yang ke 6 dan 7 sampah plastik di campur dengan sabut kelapa dipanaskan pada temperatur $155^{\circ} \mathrm{C}$. permukaan cetakan atas dan bawah dilapisi dengan plat staenless steel mendapatkan hasil produk komposit yang baik, dengan fisik warna yang sama dengan sampah plastik material awal dan juga permukaan dari komposit licin.

Alat cetak ini sangat sederhana dimana penggerak yang digunakan untuk mencetak komposit dengan menggunakan dongkrak hidrolik, dengan menbuka katup pengunci dongkrak hidrolik cetakan akan terbuka, cetakan atas bergerak keatas dibantu dengan menggunakan pegas tekan. Dengan penambahan serat sabut kelapa dan temperatur pemanasan yang sesuai akan mendapatkan hasil produk komposit yang baik dan kuat. Alat cetak ini perlu ada perbaikan selanjutnnya terutama pada elemen pemanas yang digunakan.

\section{KESIMPULAN}

Alat cetak komposit hasil pembahasan dapat disimpulkan bahwa komposit hasil dari proses uji cetak sampah plastik dengan sabut kelapa yang dicetak dengan dongkrak hidrolik 10 ton, temperatur pemanasan berkisar antara $120-150^{\circ} \mathrm{C}$, permukaan cetakan atas dan bawah dilapisi dengan plat staenless steel mendapatkan hasil cetakan yang baik, hal ini terlihat dari hasil cetakannya tidak lengket pada permukaan plat staenless steel dan tidak berubah warna sampah plastiknya.

\section{UCAPAN TERIMA KASIH}

Terima kasih kami tim peneliti yang tak terhingga pada Politeknik Negeri Manado atas bantuan dana penelitian ini sehingga terlaksana dan alat cetak dapat berfungsi walaupun belum sempurna, alat ini masih perlu untuk pengembangan lebih lanjut. 


\section{REFERENSI}

[1] Idha Zaitun Nisa Aryani Zulha Penerapan Teknologi Tepat Guna Untuk Peningkatan Pemberdayaan Masyarakat Dan Lingkungan JMM (Jurnal Masyarakat Mandiri) Vol. 2, No. 2: Desember 2018 p-ISSN 2598-8158 \& e-ISSN 2614-5758.

[2] Irvan Okatama, (2016), Analisa Peleburan Limbah Plastik Jenis Polyethylene Terphtalate (PET) Menjadi Biji Plastik Melalui Pengujian Alat Pelebur Plastik, Jurnal Teknik Mesin (JTM), Vol. 05, No. 3(2016), ISSN 2089 - 7235, Hal. 109 - 113, Jakarta.

[3] Mulinari, D.R., 2011. Mechanical Properties of Coconut Fiber Reinforced Polyester Composites. J.Engineering Procedia (Elsevier) $10: 2074$ - 2079.

[4] Romels C. A. Lumintang .,(2011) Komposit Hibrid Polyester Berpenguat Serbuk Batang dan Serat Sabut Kelapa., Jurnal Rekayasa Mesin Vol.2, No. 2 Tahun 2011 : 145-153 ISSN 0216-468X

[5] Suhasman, Astuti Arif (2007) The Resistance of Composite Boards Made from Sengon Wood Waste and Carton on Drywood Termite and Subterranean Termite . Jurnal Perennial, 4(1) : 28-35.

[6] "Pusat pengkajian dan penerapan Teknologi Lingkungan (P3TL) -BPPT dan ICS-UNDO,2002. Study on Plastic Waste management and Environmentally Degradable Plastic in Indonesia.

[7] O. Kehinde, O.J. Ramonu, K.O. Babaremu, L.D. Justin, Plastic wastes: environmental hazard and instrument for wealth creation in Nigeria. https://www.cell.com/action/showPdf?pii=S24058440\%2820\%2931974-5

[8] ASTM, https://allcivilstandard.com/astm-d-5201-03a-pdf-freedownload/

[9] Farid Mulana, Hisbullah, Iskandar, Pembuatan Papan Komposit Dari Plastik Daur Ulang dan Serbuk Kayu serta Jerami Sebagai Filler, Jurnal Rekayasa Kimia dan Lingkungan Vol. 8, No. 1, hal 17-22, 2011 ISSN 1412-5064

[10] Rizal Hanafi dkk RANCANG BANGUN MESIN HOTPRESS UNTUK PEMBUATAN PAPAN KOMPOSIT BERBASIS LIMBAH SEKAM PADI DAN PLASIK HDPE, Journal of Infrastructure \& science Engineering, Volume 2 No 1 April 2019 PISSN: 2615-6962, E-ISSN: 2614-4638. 